\title{
Prioritizing professionals? How the democratic and professionalized nature of interest groups shapes their degree of access to EU officials
}

\author{
Adrià Albareda (iD) \\ Institute of Public Administration, Leiden University, The Hague, The Netherlands \\ E-mail: a.albareda@fgga.leidenuniv.nl
}

(Received 17 January 2020; revised 07 April 2020; accepted 15 April 2020; first published online 18 June 2020)

\begin{abstract}
Interest groups are key intermediary actors between civil society and public officials. The EU has long emphasized the importance of interacting with representative groups that involve their members. Additionally, there is an increasing trend toward the professionalization of groups that invest in organizational capacities to efficiently provide policy expertise. Both member involvement and organizational capacity are crucial features for groups to function as transmission belts that aggregate and transfer the preferences of their members to policymakers, thus reinforcing the legitimacy and efficiency of governance systems. Yet, not all groups have these organizational attributes. This paper quantitatively examines the effects of interest groups' investment in member involvement and organizational capacity on the level of access to EU Commission officials. The results indicate that member involvement does not pay off in terms of higher levels of access. In contrast, groups with high organizational capacities have more meetings with public officials of the Commission.
\end{abstract}

Keywords: interest group; member involvement; organizational capacity; European Commission; level of access

\section{Introduction}

Interest groups are considered as key intermediary organizations that transmit the demands of their constituencies to public officials (Kohler-Koch, 2010; Rasmussen et al., 2014). To truly function as transmission belts, interest groups should be able to involve their members as well as have the organizational capacity to ensure an efficient articulation of policy input to public officials. Transmission belts, interest groups characterized by these two abilities, are believed to be better suited to contribute to legitimate and efficient governance systems (Saurugger, 2008; Kohler-Koch and Buth, 2013). This is particularly relevant for the European Union. Due to its democratic deficit and its limited resources, the European Commission is in need of representative and organizationally capable groups that can efficiently provide valuable policy input, thus fostering input and output legitimacy (European Commission, 2001, 2002, 2017, p. 380). However, the dual function of membership involvement and organizational capacity is mostly assumed or taken as a normative point of view, rather than being empirically tested. The literature tends to obscure such central organizational functions by relying on proxies, such as group type, which cannot be equaled to the actual capacity of groups to connect members with public officials (Binderkrantz, 2009; Klüver and Saurugger, 2013; Baggetta and Madsen, 2018). 
To address this gap, this paper develops a novel theoretical framework to examine how the ability of groups to involve their members and professionally provide policy input shapes their level of access to public officials of the European Commission. In doing so, this paper examines whether the rhetoric of the Commission, which highly values the representative nature of groups, also translates into higher levels of access for groups that meet these expectations, rather than prioritizing interactions with professionalized groups with more expert-oriented structures. Additionally, the paper unveils whether those groups that overcome the organizational tensions between representing members and professionally meeting demands from public officials (Schmitter and Streeck, 1999; Berkhout et al., 2017), and thus approximate the transmission belt ideal, gain higher levels of access to public officials of the Commission. If interest groups are one of the tools to redress the so-called democratic deficit at the EU level (Kohler-Koch and Buth, 2013; Kröger, 2016), it is necessary to open the black box and examine the effects of involving members and having organizational capacity on the level of access to the Commission.

This paper makes three contributions to the literature. First, it builds upon previous work stressing the relevance of how groups are internally organized and the significant variation in that regard (Minkoff et al., 2008; Baroni et al., 2014; Fraussen, 2014; Halpin et al., 2018) by highlighting two critical functions of groups: member involvement for representation and organizational capacity to efficiently provide policy input. Second, by examining the effects of having representative and efficient structures on the number of meetings with EU officials, the paper contributes to the literature centered on interest groups' level of access to public officials (Binderkrantz and Christiansen, 2015; Fraussen et al., 2015; Rasmussen and Gross, 2015; Grömping and Halpin, 2019; Weiler et al., 2019). Third, the paper provides an evaluation of the democratic potential of policy insider groups, which is crucial to assess how governance systems function. That is, the paper moves forward the debate on interest group bias by exploring whether membership groups that are more able to represent their constituency in an efficient and professional way gain more access to EU officials.

The paper relies on survey data from 196 groups with access to the Commission and that responded to the INTEREURO Interest Group Survey (Bernhagen et al., 2016; Beyers et al., 2016). The results indicate that the organizational capacity to efficiently generate and provide policy input matters for gaining higher levels of access to Commission officials. In contrast, investing in democratic structures does not seem to result in higher levels of access. Finally, investing in both organizational dimensions, and thus functioning as a transmission belt, does not relate to higher levels of access. These findings and their important implications for the functioning of the European Commission and the democratic character of the EU are further discussed in the final section.

\section{Explaining degree of access through an organizational approach}

This paper focuses on interest groups with access - which is conceptualized as an exchange mechanism whereby groups offer resources to public officials in exchange for meetings (Binderkrantz and Pedersen, 2017; Halpin and Fraussen, 2017). By focusing on 'insider' organizations, the paper scrutinizes an under-researched yet important aspect of interest groups - public officials' interaction, namely, the organizational factors that explain the degree of access within the set of groups that (regularly) interact with public officials (Fraussen et al., 2015). As posed by Maloney et al. (1994, p. 25), 'access merely leads to consultation, while privileged access leads to bargaining and negotiation.' More importantly, among those groups with (regular) access to public officials, few manage to achieve a privileged status by securing and frequently getting direct access to public officials, while the large majority occupy a peripheral insider position (Maloney et al., 1994, p. 17). Grossmann (2012, pp. 95-96) also highlights the importance of studying 'insider' organizations by stating that 'if $5 \%$ of organizations account for half of all participation, for example, researchers must cover that $5 \%$ to understand the dynamics of the advocacy groups that are involved in policymaking.' In other words, it is important to examine why some groups seldom meet with public officials, while others gain frequent access. 
Previous studies focusing on the level of access of interest groups have found that economic groups enjoy more access in administrative venues than citizen groups (Binderkrantz and Christiansen, 2015; Fraussen et al., 2015; Weiler et al., 2019). Rasmussen and Gross (2015, p. 358) also show that specialist groups have higher levels of access to advisory groups of the EU than diffused interest groups. While focusing on interest business associations, Kohler-Koch et al. (2017) find that representativeness (in terms of membership density) favors higher degrees of groups' reported access to the Commission and the European Parliament. Similarly, a recent research shows that the European representativeness and the organizational structure of European associations are related with access to administrative and political officials of the EU (Albareda and Braun, 2019). Finally, groups that invest more in member engagement receive positive benefits by way of a higher degree of access in the legislative arena (Grömping and Halpin, 2019) and are more likely to be political insiders (Heylen et al., 2020).

Yet, we still have scant knowledge on whether involving members as well as having professionalized organizational features leads to higher levels of access to Commission officials. There has been little conceptual work on the possible relationship among interest groups' organizational structure, their capacity to function as transmission belts, and the level of access to public officials they enjoy. To address this gap, this study conceptualizes the transmission belt ideal by focusing on the organizational ability of groups to involve members and have organizational capacity, and examines its effects on the level of access to Commission officials.

The conceptualization of transmission belts developed here applies to membership-based interest groups, as they are expected to have a representative role that one would not assume - or that is at least more complicated - for non-membership organizations (Schlozman et al., 2015). More specifically, membership-based interest groups are expected to promote a legitimate representation through processes of authorization and accountability between members and representatives. Thus, groups with members require a link to a social constituency that needs to be involved in the development of policy positions (Kröger, 2016, pp. 9-10).

The next sections present a detailed discussion of how the combination of certain organizational attributes contribute to fostering member involvement or organizational capacity and their relationship with level of access. The main expectation is that groups that invest in member involvement and organizational capacity - and approximate the transmission belt ideal - are able to provide a wider set of policy goods and, thus, are expected to gain higher levels of access to public officials.

\section{Member involvement}

Member involvement relates to those organizational features that are aimed at connecting, engaging, and interacting with members, while ensuring that the group reflects members' preferences and information. This organizational dimension speaks to the idea of representation capacity, defined as the ability of groups to speak on behalf of their members (Flöthe, 2019b). Groups that intend to foster their intermediate role are expected to have organizational mechanisms that connect them with their membership base. By doing so, they are better prepared to generate clear and authoritative statements of the political interests of the constituency they represent (Grömping and Halpin, 2019, p. 515). To achieve this, interest groups need to exhibit a governance and decision-making structure that is representative of their members and ensure that their actions reflect the shared interest of their membership base (Jordan and Maloney, 2007; Kohler-Koch, 2010).

This paper focuses on three elements that have been considered as crucial for member involvement and, thus, for the representative capacity of groups (Berkhout et al., 2017; Albareda, 2018). First, the mere existence of a forum where members and leaders of the group meet is key for member involvement, social integration, and democracy (Hayes, 1986; Jordan and Maloney, 
2007, p. 2). The second element revolves around the decision-making system and the capacity of members to determine positions and strategies of the group (Binderkrantz, 2009). In Berry et al.'s (1993) terms, involving members in the decision-making system is about the depth of participation and is expected to ensure an active involvement in the group (see also, Beyers, 2008). Finally, an important element to maintain the connection with the members is the existence of local offices, branches, or regional chapters. This feature not only enhances the embeddedness of the group in society (Fraussen et al., 2015, p. 574), but also ensures a smooth communication (and the provision of information) from geographically dispersed members to the group (Skocpol, 2003; Fraussen et al., 2015). In sum, these three factors foster the involvement of members in the group and enhance their democratic nature (Jordan and Maloney, 2007, pp. 9-10).

Interest groups that invest in member involvement are expected to have more access to public officials of the Commission. One the one hand, Commission officials are in need of input legitimacy that can be provided by representative interest groups. In that regard, as clearly posed by Kohler-Koch (2010, p. 101), 'those who want to participate in (EU) policymaking have to prove that they are representative.' The Commission itself has stated that when interest groups want to meet EU officials, 'it must be apparent (1), which interest they represent, and (2) how inclusive that representation is' (European Commission, 2002, p. 17). Similarly, the White Paper on Governance (2001), 'raised the prospect of privileged "extended partnership arrangements" in return for those groups, which could provide it with evidence of representativity' (Greenwood, 2007, p. 346; see also Persson and Edholm, 2018, p. 561). According to this EU rhetoric, those groups that have most of the organizational elements linked to member involvement will be more capable of offering input legitimacy and, thus, will have more access to the Commission. On the other hand, following an exchange approach (Bouwen, 2002), public officials are expected to grant higher levels of access to groups investing in member involvement, because they are more likely to have political information and implementation capacity. More specifically, through member involvement, groups are better able to understand and represent all members' viewpoints, experiences, and grievances (Kohler-Koch, 2010; Flöthe, 2019a). Moreover, the close-knit relationship between members and the group fosters membership compliance and, thus, implementation capacity (Braun, 2012).

Hypothesis 1: The more an interest group invests in member involvement, the more likely it is that it will gain higher degrees of access to Commission officials.

\section{Organizational capacity}

Organizational capacity relates to those organizational elements that enable groups to act in an efficient and professional manner while internally generating expertise-based information. The main assumption related to this understanding of organizational capacity is that effectiveness of interest groups is about their ability to interact with public officials. Alternative approaches to interest groups effectiveness - such as the ability to implement outside lobbying strategies (Maloney et al., 1994) - might require different organizational attributes that are not considered here (see Bryan, 2019 for a discussion on the contingent nature of organizational capacity). However, the conceptualization of organizational capacity developed below allows us to assess the ability of groups to supply timely and detailed responses to public officials with limited resources and under time constraints (Klüver, 2012; Klüver and Saurugger, 2013; Maloney, 2015). To build this organizational capacity, groups need to invest in three key organizational features: autonomy, centralized structures, and the functional differentiation that facilitates the generation of policy expertise (Albareda, 2018; Hanegraaff et al., 2019, p. 7; Klüver, 2012).

Autonomy, understood as the delegation of discretionary authority to the group, enhances managerial flexibility and efficiency (Bach, 2014, p. 345). Autonomous groups are supposed to have control over operational activities and, thus, are better equipped to function independently 
and pursue long-term strategies (Schmitter and Streeck, 1999; Beyers et al., 2008) while overcoming the hurdles of collaborative endeavors. Second, centralization or hierarchical integration implies the concentration of power on a limited number of top representatives of the group. This feature facilitates the coordination of the different tasks and activities of the group (Christensen et al., 2016). Empowering the top representatives of the organization is part of the managerialist trend that many groups have undergone and that aims to promote effective and efficient structures (Skocpol, 2003; Maloney, 2015). Finally, functional differentiation refers to the presence of specialized units that generate policy expertise on concrete issues (Hage and Aiken, 1967; Klüver, 2012). As highlighted by Klüver (2012, p. 496), groups with functional differentiation are better fitted to monitor the behavior of public officials and to notice the emergence of new policy initiatives at early stages, which enable these groups to develop expert-based information demanded by public officials. In sum, organizational capacity implies that groups are capable of generating policy expertise and efficiently processing and transferring their own resources to public officials.

Groups that invest in organizational capacity are expected to have higher degrees of access to Commission officials. Given the limited time, resources, and capacity of Commission officials as well as the transaction costs associated with meeting many stakeholders, public officials would rather meet with capable groups that have expertise and that are able to timely respond to policymakers' demands (Klüver, 2012). On the one hand, expert knowledge and technical information internally generated by specialized units are an important access good particularly for Commission officials who, as legislative agenda-setters and to develop effective policies, are in need of expert and technical information (Bouwen, 2002, 2004; Greenwood, 2011; De Bruycker, 2016). In that regard, knowledge and expertise are key sources of Commission (output) legitimacy (Kröger, 2016). On the other hand, as noted by Rasmussen and Toshkov (2013, p. 382), responsiveness of public authorities is not simply about 'giving the public what it wants but also about providing such outputs in a timely fashion.' Accordingly, public officials are expected to favor the interaction with those groups that can efficiently offer valuable information about an issue. Additionally, the emergence of capable organizations can be seen as a response of the lobbying community to EU 'pressure on interest groups to organize themselves coherently to be able to present their demands in a professional and constructive way' (Klüver and Saurugger, 2013, p. 186). Thus, when investing in organizational capacity features, interest groups are expected to gain more frequent meetings with public officials.

Hypothesis 2: The more an interest group invests in organizational capacity, the more likely it is that it will gain higher degrees of access to Commission officials.

\section{Transmission belts}

The ability to function as a transmission belt is related to the presence of organizational attributes that, on the one hand, foster the interaction and engagement with members and, on the other hand, promote the efficiency of the group by acting professionally and generating expertise-based information demanded by public officials. The paper contends that groups with an internal structure that approximates the transmission belt ideal fit better than others within the EU context, and, thus, will gain more access to public officials of the Commission. As noted before, the Commission has repeatedly stated its preferences for interacting with groups that can truly speak on behalf of their constituency (European Commission, 2001, 2002, 2017; Kohler-Koch and Buth, 2013). At the same time, previous investigations demonstrate that the population of groups mobilized at the EU level is becoming highly professionalized, a factor that is also expected to positively influence their ability to gain access to the Commission (Klüver and Saurugger, 2013; Maloney, 2015). In other words, groups that invest in member involvement and organizational capacity are expected to approximate the transmission belt ideal and successfully function 
as intermediaries between their constituency and public officials, thereby contributing to EU governance systems with input and output legitimacy.

However, having most of the organizational elements of both dimensions may be associated with organizational tensions. Interest groups struggle to combine organizational features that reinforce the democratic nature of groups by involving members, with other features aimed at being efficient and at generating policy expertise (Schmitter and Streeck, 1999; Jordan and Maloney, 2007; Skocpol, 2003; Klüver and Saurugger, 2013; Maloney, 2015; Berkhout et al., 2017). As noted by van der Pijl and Sminia (2004)), these two organizational dimensions are in conflict, because one follows a bottom-up process that emphasizes the inclusion of all the different voices within the organization whereas the other follows a top-down approach that relies on values such as efficiency and control over members. Functioning as a transmission belt, thus, puts substantial and sometimes contradictory organizational demands on groups (Berkhout et al., 2017). However, some groups are able to overcome these tensions and effectively organize themselves as transmission belts (Albareda, 2018). These groups are not only able to provide public officials with input legitimacy, but also function in an efficient and professional manner, which reinforces the output legitimacy of the political process. Hence, groups that invest in both organizational dimensions will have higher levels of access than those that only invest in one of them.

Hypothesis 3a: Interest groups organized as transmission belts are more likely to gain higher degrees of access to Commission officials than those that are not organized as transmission belts.

Hypothesis 3b: The effects of functioning as a transmission belt on the likelihood of gaining more access to the Commission are higher than the one obtained by interest groups investing in either member involvement or organizational capacity.

\section{Research design}

The paper relies on data from the INTEREURO Interest Group Survey, ${ }^{1}$ a tool designed within the INTEREURO project to examine organizational characteristics and policy activities of interest groups active at the EU level. The survey was conducted from 9 March to 2 July 2015 and targeted senior leaders of the interest groups (Bernhagen et al., 2016). In total, 2038 interest organizations were selected from the Transparency Register of the EU, the OECKL Directory. ${ }^{2}$ To be included in the sample, the organizations had to fulfil three requirements: (1) EU-level interest organizations, which could be EU peak associations or national organizations with (2) a presence in Brussels and (3) that show some interest in EU policymaking processes. The organizations included in the sample fit perfectly the purpose of this study, because, due to their layered structure, they require to put in place a certain organizational structure that defines the interaction between members. The last section of the paper discusses how the focus on interest groups active at the EU level may have consequences for the occurrence of our explanatory factors and, thus, for the generalizability of the results.

Despite the hurdles related to gaining organizational data of interest groups (Baggetta and Madsen, 2018), 738 groups completed the questionnaire, reaching a response rate of $36.2 \%$ (Beyers et al., 2016). To enable the identification of group type (i.e. business vs. non-business groups), only membership-based groups that were accurately categorized are included. Groups that did not provide such information $(n=128)$ were excluded from the sample. Additionally,

\footnotetext{
${ }^{1}$ See: http://www.cigsurvey.eu/data

${ }^{2}$ See: https://acim.uantwerpen.be/files/documentmanager/project/survey_samplingmemo_intereuro.pdf
} 
groups without members $(n=48)$ have been dropped from the database, leading to 559 interest groups for which survey data are available.

The bottom-up sampling approach used to obtain the sample of groups included in the survey entails an important limitation, namely, that it does not represent a perfect match for studies on interest group influence due to the long chain of intermediate steps between mobilization and final policy outcomes (Berkhout et al., 2018). However, this dataset of 559 groups is combined with the 'Transparency International EU - Integrity Watch' database of interest groups with access to public officials of the Commission - i.e. Commissioners, their Cabinets, and Director-Generals (European Commission, 2014). ${ }^{3}$ In total, 196 out of the 559 membership-based groups that responded to the INTEREURO survey had at least one meeting with public officials between December 2014 and October 2017.

\section{Dependent variable: access to public officials of the European Commission}

The hypotheses drawn in the previous section are tested by focusing on the level of access that interest groups obtain to Commission officials. Since the approval of the White Paper on European Governance in 2001, the Commission has been progressively developing 'one of the most elaborate and ambitious consultative regimes' (Bunea, 2017, p. 47). At a general level, the consultation regime of the EU aims to promote a balanced involvement and participation of different non-state stakeholders, to reinforce the societal legitimacy of EU institutions, and to efficiently and effectively develop legislative proposals by interacting with actors that will be affected and that possess relevant knowledge (European Commission, 2001; Kröger, 2016, p. 27). To do so, the Commission has put in place multiple consultation mechanisms, both open and targeted (European Commission, 2017; Fraussen et al., 2020).

This paper focuses on one specific consultation mechanism, namely, direct - face-to-face and often individual - meetings between interest group representatives and public officials of the Commission. Importantly, there is no clear set of rules defining which groups are invited to the meetings studied here (Kröger, 2016, p. 25). However, direct meetings constitute an important form of access, as they are expected to have the highest degree of interactivity and involvement between officials and group representatives when compared with other public and targeted consultation mechanisms (European Commission, 2017, pp. 395-396).

To examine the relationship between degree of access and the presence of key organizational features related to the transmission belt ideal, the paper only includes groups that had at least one meetings with a Commission official between December 2014 and October 2017, and measures the degree of access by the number of meetings they had in this period. By focusing on level of access, this paper intends to capture which organizational dimensions facilitate a repeated interaction with public officials and, thus, can get a status closer to what has been labelled as 'core' insiders (Fraussen et al., 2015). Additionally, this operationalization of the dependent variable accounts for the limited knowledge that public officials may have about interest groups' organizational structures. It is fair to assume that public officials do not know whether groups invest in member involvement and/or organizational capacity. However, this is probably clarified after the first meeting, and thus, if involving members or having organizational capacity matters, it can be observed with the subsequent meetings between the group and public officials. Despite this focus on groups with access, the paper also includes additional analyses that examine the effects of the explanatory variables on the likelihood of gaining access. In this case, the variable is either 0 or 1 . These analyses include the 559 membership-based groups that responded to the INTEREURO survey of which $35 \%$ gained access to Commission officials in the specified period.

\footnotetext{
${ }^{3}$ The data are offered in an aggregate manner by Transparency International - Integrity Watch. See: http://www. integritywatch.eu/about.html
} 


\section{Explanatory factors: member involvement, organizational capacity, and transmission belts}

Table 1 presents the operationalization of the two organizational dimensions. Member involvement is an additive index that includes the following organizational features: interaction among members, decision-making procedure, and the presence of local branches. The first item focuses on the presence or absence of a forum that facilitates the interaction among members or supporters (Hayes, 1986; Jordan and Maloney, 2007). Despite being a restricted operationalization that does not account for the frequency of these meetings or their turnout, the presence of such a forum is considered as a prerequisite to enable the interaction among members and between members and the organization (Jordan and Maloney, 2007, p. 2). The second feature looks at the decision-making procedure and, in particular, at whether members have the capacity to determine the positions and strategies of the group either through consensus or voting mechanisms (Binderkrantz, 2009). This measurement is about the depth of participation of members regarding key factors for the mission and the future of the organization (Berry et al., 1993) and relates to the perceived legitimacy that members confer to the group (Persson et al., 2013). The last item centers on the presence or absence of local branches that foster the connections between the group and its local/regional constituency (Skocpol, 2003; Fraussen et al., 2015). That is, it looks at the organizational ability of the group to reach out to elementary members spread around a Member State, Europe, or even internationally.

Organizational capacity is an additive index of three organizational elements: autonomy, centralization, and functional differentiation. Autonomy is measured using a question about whether the group can independently hire their own staff and approve the budget or if, in contrast, both tasks require the approval of the members (either directly or through the board of directors) (Bach, 2014). That is, the focus is on operational autonomy, which, in this case, indicates whether a group can take human resource management decisions without membership involvement. As noted by Bach $(2014$, p. 345), this is a powerful indicator of the 'degree of [member] interference in the day-to-day management of the [group].' Centralization is operationalized as a construct that captures whether the apex of the group (i.e. executive director, the chair of the board, and the board of directors) is influential when establishing positions and deciding on advocacy tactics (Christensen et al., 2016). The paper, thus, examines real authority, which is expected to provide a more accurate measurement, because some organizations may have decentralized decision-making structures, but, in practice, the power/influence might be concentrated around the apex of the organization (Pugh et al., 1963). Finally, functional differentiation is measured by examining the presence or absence of committees for specific tasks (Hage and Aiken, 1967), which enable the organization to produce expert knowledge in a timely manner (Klüver, 2012).

The items in each organizational dimension serve to compute two additive multi-dimensional factors (or composites) that range from 0 to 3 (see Berkhout et al., 2017 for a similar approach). In doing so, the paper establishes two composite factors that are formed when individual indicators are compiled into a single index on the basis of an underlying model of the multi-dimensional concept that is being measured' (Greco et al., 2019). In this case, the (non-weighted) three items included in each factor are conceptually related, but they represent different organizational dimensions, and, thus, are not statistically correlated (see Table A0 in Appendix I). For more details on the original questions used to operationalize each of the items and the correlation between them, see Appendix I.

The third explanatory variable - i.e. the organizational ability to function as a transmission belt - is operationalized as a binary factor that is coded as 1 when groups score 2 or 3 in both 'member involvement' and 'organizational capacity.' In other words, those interest groups that score highly on both organizational dimensions are coded as a transmission belt. This operationalization follows an organizational configuration approach and considers transmission belts those interest groups that have at least two critical organizational features related to each organizational dimension (for a similar operationalization of the transmission belt factor, see Berkhout et al., 
Table 1 Operationalization of organizational variables

\begin{tabular}{|c|c|}
\hline Items & Operationalization \\
\hline \multicolumn{2}{|c|}{ Member involvement: Additive index ranging from 0 to 3} \\
\hline \multirow[t]{2}{*}{ Interaction among members } & $\begin{array}{l}0=\text { Organizations do not have a general assembly or } \\
\text { an annual general meeting. }\end{array}$ \\
\hline & $\begin{array}{l}1=\text { Organizations have a general assembly or an } \\
\text { annual general meeting. }\end{array}$ \\
\hline \multirow[t]{2}{*}{ Decision-making procedure } & $\begin{array}{l}0=\text { Members do not participate in the decision-making } \\
\text { processes when establishing positions and defining } \\
\text { strategies. }\end{array}$ \\
\hline & $\begin{array}{l}1 \text { = Members participate in the decision-making } \\
\text { processes when establishing positions and defining } \\
\text { strategies. }\end{array}$ \\
\hline \multirow[t]{2}{*}{ Local branches } & $\begin{array}{l}0=\text { Organizations do not have local or regional } \\
\text { chapters. }\end{array}$ \\
\hline & $1=$ Organizations have local or regional chapters. \\
\hline \multicolumn{2}{|c|}{ Organizational capacity: Additive index ranging from 0 to 3} \\
\hline \multirow[t]{2}{*}{ Autonomy } & $\begin{array}{l}0=\text { The senior staff of the organization does not have } \\
\text { decision-making power on the budget or on hiring } \\
\text { staff. }\end{array}$ \\
\hline & $\begin{array}{c}1=\text { The senior staff of the organization has decision- } \\
\text { making power on the budget and on hiring staff. }\end{array}$ \\
\hline Centralization & $\begin{array}{l}0=\text { The apex of the group is not influential when } \\
\text { establishing positions and defining strategies. } \\
1=\text { The apex of the group is influential when } \\
\text { establishing positions and defining strategies. }\end{array}$ \\
\hline \multirow[t]{2}{*}{ Functional differentiation } & $\begin{array}{l}0=\text { Organizations do not have committees for specific } \\
\text { tasks. }\end{array}$ \\
\hline & $1=$ Organizations have committees for specific tasks. \\
\hline
\end{tabular}

2017, p. 1118). An alternative would be operationalizing this variable as an additive index of the two organizational dimensions, that is, ranging from 0 to 6 , but the problem with this approach is that it does not enable us to examine how the presence of both dimensions affects levels of access. Similarly, studying this variable as an interaction effect between the two organizational dimensions would not allow us to disentangle which groups can be categorized as transmission belts.

\section{Control variables}

The paper controls for well-established variables that tap into groups' characteristics and that relate to their capacity to provide different access goods to public officials. The first control is group type. It is included as a dichotomous variable indicating whether groups are business (e.g. European Dairy Association or the International Union of Combined Road-Rail Transport Companies) or non-business (e.g. European Consumer Organization or the European Federation of Employees in Public Services). Business groups are expected to be better represented in administrative venues such as the Commission (e.g. Fraussen et al., 2015; Kohler-Koch et al., 2017; Weiler et al., 2019). Moreover, recent research has demonstrated that business organizations face more difficulties than citizen groups when establishing policy positions on specific policy issues, which implies that they have a more active involvement of their members (De Bruycker et al., 2019). Related, the correlation matrix in Appendix II shows that business organizations are more likely to approximate the transmission belt ideal, and thus, it is important to control for this in the multivariate models.

The second control distinguishes whether organizations are mobilized at a national or supranational level (Bunea, 2014). Aligned with previous studies, the Commission is expected to favor 
the interaction with groups representing encompassing interests that go beyond their national preferences (Bouwen, 2004; Bunea, 2014). Third, the scope of activity of the group - measured with the number of policy domains or sectors in which the group is involved - is included as a control. Here, the distinction is between generalists and niche players, and the formers are expected to have more access to the Commission, because they are active in more policy domains. Fourth, membership diversity is included as a count variable to assess the effect of having a diverse set of members on degree of access. The membership options are: private citizens, firms, local and regional governments, national associations, and European associations.

Organizational age and resources are also included as controls. In line with previous studies, organizational age is expected to have a positive effect on the level of access to public officials, because older groups may have more expertise to engage in lobbying and a wider circle of contacts among public officials (Dür and Mateo, 2014; Fraussen et al., 2015). The financial resources of the organizations are measured in terms of full-time equivalents (FTE) and are expected to positively relate with access (Dür and Mateo, 2014; Kröger, 2016, p. 187). Although resources on their own cannot fully explain why groups get engaged in EU politics, they may have an effect on interest groups' abilities to involve their members and develop the necessary organizational capacities to efficiently engage with public officials (Kröger 2016, p. 188). Yet, as reported in the correlation matrix in Appendix II, the variable resources are not correlated with the explanatory factors, suggesting that 'resources cannot explain why we find different patterns of organizational structures among groups' (Hollman, 2018).

\section{Analyses and results}

Before turning to the regression analyses, this paragraph describes the explanatory variables, as well as the bivariate relationship between them and the dependent variable. First, groups on average invest somewhat more in organizational capacity than in member involvement. More specifically, as shown in Table A2 in Appendix II, groups score 1.486 (S.D. 0.643) and 1.787 (S.D. 0.481) for member involvement and organizational capacity, respectively. In addition, $37 \%$ of the interest groups in the analysis are organizationally prepared to function as transmission belts. Second, regarding the bivariate analysis, the three explanatory variables are positively related to the degree of access interest groups gain to Commission officials. However, as shown in the correlation matrix (Appendix II), the only variable that is significantly related to the degree of access is organizational capacity.

Regarding the multivariate analyses, Table 2 presents the results of negative binomial regressions that have as dependent variable the level of access, that is, the number of meetings with public officials of the Commission. This is an appropriate method, because the dependent variable is an over-dispersed count variable that ranges from 1 to 116 , with a mean of 8.204, and a standard deviation of 15.431 (Long and Freese, 2014).

First, Hypothesis 1 is rejected. Results in Models 1, 3, and 5 indicate that those groups that invest in involving their members via direct contact and decision-making procedures are not more likely to gain higher levels of access to the Commission. In fact, the predicted number of meetings when groups do not have the organizational features that empower their members is 13.771 (SE: 7.964), and when groups have the three features related to member involvement, this decreases to 5.969 (SE: 2.757). ${ }^{4}$ This finding contradicts the rhetoric of the Commission and its request for representative and democratic interest groups (European Commission, 2001, 2002). The nonsignificant relation may be a consequence of the transaction and coordination costs associated with involving members, which hamper the efficiency of the group and their ability to provide timely and relevant policy input. The null finding also indicates that public officials are not actively reaching out to those groups that are more representative of their membership base.

${ }^{4}$ The predicted number of meetings presented in the analyses is based on Model 5 of Table 2 . 
Table 2 Negative binomial regression: level of access to commission officials ${ }^{1}$

\begin{tabular}{|c|c|c|c|c|c|}
\hline & Model 1 & Model 2 & Model 3 & Model 4 & Model 5 \\
\hline Member involvement & $-0.010(0.215)$ & & $-0.150(0.198)$ & & $-0.279(0.331)$ \\
\hline Organizational capacity & & $0.861^{\star \star \star}(0.229)$ & $0.869^{\star \star \star}(0.228)$ & & $0.782^{\star \star \star}(0.292)$ \\
\hline Transmission belt & & & & $0.302(0.255)$ & $0.214(0.449)$ \\
\hline $\begin{array}{l}\text { Group type: Non-business } \\
\text { (REF) }\end{array}$ & & & & & \\
\hline $\begin{array}{l}\text { Group type: Business } \\
\text { Org. scale: (Sub)National } \\
\quad \text { associations (REF) }\end{array}$ & $0.045(0.249)$ & $-0.223(0.236)$ & $-0.169(0.246)$ & $-0.089(0.250)$ & $-0.157(0.245)$ \\
\hline $\begin{array}{l}\text { Org. scale: European } \\
\text { or International } \\
\text { associations }\end{array}$ & $0.7912^{\star \star}(0.378)$ & $0.649^{\star}(0.361)$ & $0.690^{\star}(0.363)$ & $0.705^{\star}(0.376)$ & $0.700^{\star}(0.363)$ \\
\hline Scope of activity & $0.117^{\star \star}(0.046)$ & $0.092^{\star \star}(0.042)$ & $0.095^{\star \star}(0.041)$ & $0.116^{\star \star}(0.046)$ & $0.100^{\star \star}(0.043)$ \\
\hline Membership diversity & $-0.348^{\star \star \star}(0.121)$ & $-0.332^{\star \star \star}(0.113)$ & $-0.344^{\star \star \star}(0.113)$ & $-0.310^{\star \star}(0.122)$ & $-0.335^{\star \star \star}(0.115)$ \\
\hline Organizational age & $-0.005(0.005)$ & $-0.002(0.005)$ & $-0.003(0.005)$ & $-0.003(0.006)$ & $-0.003(0.005)$ \\
\hline Resources (FTE) & $0.009^{\star \star}(0.004)$ & $0.008^{\star \star}(0.003)$ & $0.008^{\star \star *}(0.003)$ & $0.008^{\star \star}(0.004)$ & $0.009^{\star \star \star}(0.003)$ \\
\hline Constant & $1.488^{\star \star}(0.591)$ & $-0.006(0.624)$ & $0.155(0.654)$ & $1.258^{\star \star}(0.547)$ & $0.361(0.785)$ \\
\hline $\mathrm{N}$ & 107 & 107 & 107 & 107 & 107 \\
\hline Alpha & $1.193(0.163)$ & $1.067(0.150)$ & $1.060(0.150)$ & $1.182(0.162)$ & $1.057(0.150)$ \\
\hline Log likelihood & -329.659 & -323.238 & -322.954 & -329.060 & -322.841 \\
\hline
\end{tabular}

${ }^{\star} P<0.1 ;{ }^{\star \star} P<0.05 ;{ }^{\star \star *} P<0.01$.

${ }^{1}$ The $t$-test analyses indicate that neither the dependent variable nor the main explanatory and control factors are biased due to missing data. Vif scores in range from 1.06 to 4.12 , suggesting that multicollinearity is not a problem.

Models 2, 3, and 5 confirm Hypothesis 2. Groups that have more organizational capacity are more likely to gain more access to public officials of the Commission. The predicted number of meetings with public officials increases from 2.055 (SE: 1.170) when groups do not have any feature related to organizational capacity to 21.463 (SE: 8.552) and when they have the three organizational attributes. This finding relates to the preference of EU institutions for developed and professional organizations (Klüver and Saurugger, 2013; Maloney, 2015). Aligned with previous findings, this result shows that investing in efficient and professionalized structures that generate expertise-based information facilitates access to the Commission (Klüver, 2012; Berkhout et al., 2017). More importantly, this finding underlines the agency of groups when gaining more access to the Commission - organizationally capable groups have a clear advantage in that regard.

Finally, as depicted in Models 4 and 5, interest groups organized as transmission belts do not have higher levels of access; thus, Hypothesis $3 \mathrm{a}$ and Hypothesis $3 \mathrm{~b}$, respectively, are rejected. More specifically, $37 \%$ of the interest groups in the analysis that overcome the tensions of balancing member involvement and organizational capacity and, hence, that are expected to offer both input legitimacy and efficiency do not have more access to public officials of the Commission. The predicted number of meetings of groups that are not categorized as transmission belts is 7.927 meetings (SE: 1.835), whereas transmission belts have 9.820 (SE: 3.026). In that regard, being organizationally prepared to function as a transmission belt leads to more meetings, but this difference is not statistically significant. Consequently, the relationship between interest group structure and access is dominated by their investment in organizational capacity, whereas involving members seems to decrease the ability or the attractiveness of groups to gain access to public officials.

Regarding the control variables in Model 5, being a generalist, mobilizing at the EU/ international level, and having more resources are positively related to the level of access. In contrast, groups including a more diverse set of actors are less likely to gain higher levels of access. As shown by Kröger (2018), groups with a heterogeneous membership-base face more difficulties to find common ground beyond the lowest common denominator, which ultimately might be hampering their ability to be politically active. Another intriguing result is that group type does not matter in any of the models. In contrast to other institutional settings, such as Belgium (Fraussen et al., 2015), Denmark (Binderkrantz and Christiansen, 2015), and Switzerland 
(Weiler et al., 2019), results indicate that, in the Commission, being a business organization does not affect the level of access to public officials. One possible explanation of this null finding is the time-consuming process of internal consensus formation that business organizations, particularly at the EU level, necessitate to define policy positions (De Bruycker et al., 2019). All in all, the results of the control variables underline the necessity to more accurately unpack the relationship among membership diversity, group type, organizational structure, and access or influence.

\section{Additional analyses and robustness tests}

This paper focuses on explaining the degree of access that interest groups obtain to public officials. However, access can be conceptualized as a two-step process in which first interest groups gain access, and, subsequently, they can have repeated access. This section evaluates the robustness of the results while accounting for those organizations without access. More specifically, Table 3 presents the results of hurdle negative binomial models, a two-step method that first assesses the probability of obtaining the binary outcome, in this case obtaining access or not, and subsequently calculates the effects of the same explanatory factors on the level of access (see Weiler et al., 2019 for a similar approach). This model is appropriate in the case of a sequential decision-making process. Even though the two stages of granting access once and deciding to grant access multiple times are estimated separately, the second stage should be interpreted as conditional on the first stage.

The first step of the model (binary logit) shows that organizational capacity increases the likelihood of gaining access. In contrast, member involvement and functioning as a transmission belt are not related to the probability of gaining access. ${ }^{5}$ That is, the same organizational factors that explain the level of access seem to explain the likelihood of gaining access. Additionally, the second step of the model (zero-truncated negative binomial) confirms the results presented in Table 2. The only differences are found in the significance levels of some control variables. More specifically, the second step of hurdle models shows that only organizational scale and resources are significantly related to the degree of access, yet this result is not consistent across all model specifications in Table 3. Appendix III presents additional robustness checks that further confirm the results reported in Tables 2 and 3.

\section{Discussion and conclusions}

This paper develops a novel theoretical approach to study how interest groups' member involvement and organizational capacity affect their degree of access to EU public officials. In this way, the findings inform us about the potential democratic contribution of groups with access to Commission officials - who are expected to reach out to groups that can increase the legitimacy and efficiency of the policy process.

Before discussing the main findings, this last section will reflect on three aspects related to the research design. First, this paper has analyzed how interest groups' organizational structure affects access using reported survey data that tap key organizational elements. Thus, the paper looks at the formal opportunities for the participation of members, and not at the actual involvement of members. In addition to examining actual involvement of members, future research could examine whether the organizational structures related to member involvement lead to an accurate alignment of the preferences of members and the positions of group leaders (Kröger, 2016, 2018).

Second, the groups included in the sample are active at the EU level and gained access to Commission officials. The need for professionalized and technical expertise might be accentuated in the Commission, which as the bureaucratic institution in charge of developing policy proposals

\footnotetext{
${ }^{5}$ In total, 287 organizations have been excluded from the analysis due to missing values. The $t$-test analyses indicate that neither the dependent variable nor the main explanatory and control factors are biased due to missing data.
} 
Table 3 Hurdle negative binomial: access and level of access to commission officials

\begin{tabular}{|c|c|c|c|c|c|c|c|c|c|c|}
\hline & \multicolumn{5}{|c|}{ Access } & \multicolumn{5}{|c|}{ Level of access } \\
\hline & Model 1 & Model 2 & Model 3 & Model 4 & Model 5 & Model $1 b$ & Model $2 b$ & Model 3b & Model $4 b$ & Model 5b \\
\hline Member involvement & $\begin{array}{c}-0.0381 \\
(0.212)\end{array}$ & & $\begin{array}{l}-0.086 \\
(0.216)\end{array}$ & & $\begin{array}{c}0.032 \\
(0.349)\end{array}$ & $\begin{array}{c}0.163 \\
(0.436)\end{array}$ & & $\begin{array}{l}-0.103 \\
(0.503)\end{array}$ & & $\begin{array}{l}-0.074 \\
(0.657)\end{array}$ \\
\hline Organizational capacity & & $\begin{array}{l}0.484^{\star \star} \\
(0.242)\end{array}$ & $\begin{array}{l}0.494^{\star *} \\
(0.243)\end{array}$ & & $\begin{array}{l}0.546^{\star \star} \\
(0.273)\end{array}$ & & $\begin{array}{l}1.058^{\star \star} \\
(0.524)\end{array}$ & $\begin{array}{l}1.163^{\star \star} \\
(0.525)\end{array}$ & & $\begin{array}{l}1.193^{*} \\
(0.680)\end{array}$ \\
\hline Transmission belt & & & & $\begin{array}{c}0.064 \\
(0.273)\end{array}$ & $\begin{array}{l}-0.203 \\
(0.475)\end{array}$ & & & & $\begin{array}{c}0.443 \\
(0.490)\end{array}$ & $\begin{array}{l}-0.055 \\
(0.825)\end{array}$ \\
\hline Group type: Non-business (REF) & & & & & & & & & & \\
\hline $\begin{array}{l}\text { Group type: Business } \\
\text { Org scale: (Sub)National associations (REF) }\end{array}$ & $\begin{array}{l}0.626^{\star \star} \\
(0.274)\end{array}$ & $\begin{array}{l}0.590^{\star \star *} \\
(0.276)\end{array}$ & $\begin{array}{l}0.594^{\star \star} \\
(0.276)\end{array}$ & $\begin{array}{l}0.620^{\star \star} \\
(0.274)\end{array}$ & $\begin{array}{l}0.594^{\star \star} \\
(0.276)\end{array}$ & $\begin{array}{c}0.089 \\
(0.475)\end{array}$ & $\begin{array}{l}-0.249 \\
(0.489)\end{array}$ & $\begin{array}{l}-0.248 \\
(0.489)\end{array}$ & $\begin{array}{l}-0.009 \\
(0.484)\end{array}$ & $\begin{array}{l}-0.253 \\
(0.493)\end{array}$ \\
\hline Org. scale: European or International associations & $\begin{array}{l}1.006^{\star \star} \\
(0.402)\end{array}$ & $\begin{array}{l}0.920^{\star \star} \\
(0.404)\end{array}$ & $\begin{array}{l}0.938^{\star \star} \\
(0.407)\end{array}$ & $\begin{array}{l}0.989^{\star *} \\
(0.401)\end{array}$ & $\begin{array}{l}0.932^{\star \star} \\
(0.407)\end{array}$ & $\begin{array}{l}1.611^{* *} \\
(0.787)\end{array}$ & $\begin{array}{l}1.356^{*} \\
(0.781)\end{array}$ & $\begin{array}{l}1.146 \\
(0.913)\end{array}$ & $\begin{array}{l}1.591^{\star \star} \\
(0.783)\end{array}$ & $\begin{array}{c}1.145 \\
(0.884)\end{array}$ \\
\hline Scope of activity & $\begin{array}{c}0.115^{\star \star \star} \\
(0.043)\end{array}$ & $\begin{array}{c}0.113^{\star \star \star} \\
(0.044)\end{array}$ & $\begin{array}{c}0.114^{\star \star \star} \\
(0.044)\end{array}$ & $\begin{array}{c}0.114^{\star \star \star} \\
(0.043)\end{array}$ & $\begin{array}{c}0.114^{\star \star \star} \\
(0.044)\end{array}$ & $\begin{array}{c}0.069 \\
(0.097)\end{array}$ & $\begin{array}{c}0.107 \\
(0.093)\end{array}$ & $\begin{array}{c}0.119 \\
(0.093)\end{array}$ & $\begin{array}{c}0.089 \\
(0.101)\end{array}$ & $\begin{array}{l}0.117 \\
(0.096)\end{array}$ \\
\hline Membership diversity & $\begin{array}{c}-0.223^{*} \\
(0.115)\end{array}$ & $\begin{array}{c}-0.226^{*} \\
(0.116)\end{array}$ & $\begin{array}{c}-0.229^{\star *} \\
(0.116)\end{array}$ & $\begin{array}{c}-0.219^{\star} \\
(0.115)\end{array}$ & $\begin{array}{c}-0.233^{* *} \\
(0.116)\end{array}$ & $\begin{array}{l}-0.036 \\
(0.265)\end{array}$ & $\begin{array}{l}-0.300 \\
(0.338)\end{array}$ & $\begin{array}{l}-0.441 \\
(0.492)\end{array}$ & $\begin{array}{l}-0.024 \\
(0.262)\end{array}$ & $\begin{array}{l}-0.447 \\
(0.477)\end{array}$ \\
\hline Organizational age & $\begin{array}{l}-0.004 \\
(0.005)\end{array}$ & $-0.005(0.006)$ & $\begin{array}{l}-0.005 \\
(0.006)\end{array}$ & $\begin{array}{l}-0.004 \\
(0.006)\end{array}$ & $\begin{array}{l}-0.005 \\
(0.006)\end{array}$ & $\begin{array}{l}-0.012 \\
(0.013)\end{array}$ & $\begin{array}{l}-0.011 \\
(0.013)\end{array}$ & $\begin{array}{l}-0.008 \\
(0.014)\end{array}$ & $\begin{array}{l}-0.013 \\
(0.013)\end{array}$ & $\begin{array}{l}-0.008 \\
(0.014)\end{array}$ \\
\hline Resources (FTE) & $\begin{array}{l}0.008^{\star \star} \\
(0.004)\end{array}$ & $\begin{array}{l}0.007^{\star \star} \\
(0.004)\end{array}$ & $\begin{array}{l}0.008^{\star \star} \\
(0.004)\end{array}$ & $\begin{array}{l}0.007^{\star \star} \\
(0.004)\end{array}$ & $\begin{array}{l}0.008^{\star \star} \\
(0.004)\end{array}$ & $\begin{array}{l}0.093^{\star \star} \\
(0.039)\end{array}$ & $\begin{array}{c}0.039 \\
(0.037)\end{array}$ & $\begin{array}{c}0.021 \\
(0.048)\end{array}$ & $\begin{array}{l}0.085^{\star \star} \\
(0.039)\end{array}$ & $\begin{array}{c}0.021 \\
(0.045)\end{array}$ \\
\hline Constant & $\begin{array}{c}-1.640^{\star \star \star} \\
(0.608)\end{array}$ & $\begin{array}{c}-2.411^{\star \star \star} \\
(0.675)\end{array}$ & $\begin{array}{c}-2.322^{\star \star \star} \\
(0.711)\end{array}$ & $\begin{array}{c}-1.698^{\star \star \star} \\
(0.554)\end{array}$ & $\begin{array}{c}-2.503^{\star \star \star} \\
(0.832)\end{array}$ & $-16.08(20.31)$ & $\begin{array}{l}-13.90 \\
(131.8)\end{array}$ & $\begin{array}{l}-3.078 \\
(6.373)\end{array}$ & $\begin{array}{l}-13.48 \\
(65.95)\end{array}$ & $\begin{array}{l}-3.125 \\
(6.067)\end{array}$ \\
\hline Inalpha & $\begin{array}{c}16.11 \\
(20.32)\end{array}$ & $\begin{array}{c}13.58 \\
(131.8)\end{array}$ & $\begin{array}{c}3.234 \\
(5.146)\end{array}$ & $\begin{array}{c}13.66 \\
(65.95)\end{array}$ & $\begin{array}{c}3.231 \\
(4.882)\end{array}$ & $\begin{array}{c}16.11 \\
(20.32)\end{array}$ & $\begin{array}{c}13.58 \\
(131.8)\end{array}$ & $\begin{array}{c}3.234 \\
(5.146)\end{array}$ & $\begin{array}{c}13.66 \\
(65.95)\end{array}$ & $\begin{array}{c}3.231 \\
(4.882)\end{array}$ \\
\hline Log likelihood & -461.502 & -457.876 & -457.823 & -461.148 & -457.729 & -461.502 & -457.876 & -457.823 & -461.148 & -457.729 \\
\hline $\mathrm{N}$ & 272 & 272 & 272 & 272 & 272 & 107 & 107 & 107 & 107 & 107 \\
\hline
\end{tabular}

${ }^{\star} P<0.1 ;{ }^{* \star} P<0.05 ;{ }^{\star \star \star} P<0.01$

272

272

272

272

107

107

107

107

107 
is mostly concerned about the technicalities that would make a proposal viable. We may find different results if we study more politicized venues, such as the legislative arena where there is a higher demand for political knowledge (Grömping and Halpin, 2019). In addition, the effects of these organizational dimensions and the ability to function as a transmission belt might work differently at the national level (see Berkhout et al., 2017). In that regard, members might have few selective incentives to get involved in the groups due to its EU focus, which could ultimately affect the organizational attributes to involve members and have organizational capacity. Future research needs to assess the occurrence and validity of the main explanatory factors and their effects on the degree of access in (sub)national polities.

Finally, the paper focuses on the transmission belt function of membership-based interest groups. That is, it excludes non-membership organizations which according to the Transparency Register represent almost half of the interest groups with access to Commission officials. The main argument to exclude these organizations is that they do not have the (implicit) responsibility to take into account the concerns of members and to be representative of their constituency. However, non-membership interest groups can develop important functions that complement and support the representative role of membership-based interest groups (Walker et al., 2011). Future research should delve into the relationship between membership and non-membership-based groups to more accurately assess the transmission belt function.

Despite these limitations, the analyses demonstrate that the most important organizational dimension to gain more access to the Commission is organizational capacity. This finding goes somewhat against the rhetoric of the Commission and its presumed willingness to interact with representative groups to compensate for its democratic deficit and expand the societal legitimacy of EU public policies (Kohler-Koch, 2010). Contrary to what is expected, based on this rhetoric, groups that invest time and resources on democratic and representative structures do not gain more access to the Commission, which contrasts with previous research focused on European associations (Albareda and Braun, 2019). Hence, the Commission has not yet put into practice the 'privileged partnership' arrangement with interest groups on the basis of representativeness criteria (European Commission, 2001; Pérez-Solórzano Borragán, 2014, p. 135). In contrast, the results indicate that the Commission mostly values efficient and professionalized groups that are able to efficiently respond to public officials' demands, and provide them with valuable policy expertise (see also Klüver, 2012). In line with Majone's (1999) proposal, the EU's main concern appears to be output legitimacy, which it seeks to obtain through technocratic principles and prioritizing interactions with professionalized groups.

From an interest groups perspective, these results suggest that the inefficiency costs related to member involvement come at a price of lower reactivity at the EU level (Hollman, 2018) and negatively affects access to administrative venues (Willems, 2020). In other words, for groups that enjoy high levels of access, maintaining member involvement might be very challenging, as it is rather costly and time-consuming, and might reduce their decision-making speed. What is more, groups that have complex organizational structures that combine member involvement and organizational capacity, and thus can offer a wider range of policy goods and provide them in an efficient manner, do not see any benefit in terms of more access to public officials. Thus, what matters for groups aiming to gain more meetings with Commission officials is to invest in professionalized structures that generate expertise and facilitate efficient policy responses to public officials' demands.

According to these findings, the interaction between interest groups and EU public officials is biased in favor of groups that may not be organizationally equipped to talk on behalf of their constituency, thus decreasing the input legitimacy of the EU governance system (Kröger, 2014). This might be problematic from a democratic perspective as 'interest groups may be more willing to listen to the arguments of policymakers than represent the interests of their members' (Berkhout et al., 2017, p. 1110; see also Kröger, 2016, p. 17). At a general level, these findings also raise the important question of whether Commission officials, and the EU more broadly, are active enough in reaching out to groups that make big efforts to involve and represent their constituency. 
Supplementary material. To view supplementary material for this article, please visit https://oi.org/10.1017/ S1755773920000247.

Acknowledgements. I would like to thank the journal editors, as well as three anonymous referees, for their valuable feedback and comments. I am grateful to Caelesta Braun, Bert Fraussen, Moritz Müller, and Erin Sullivan for their valuable advice and support. I would also like to thank all the scholars involved in the INTEREURO Interest Group Survey for granting me access to the survey data as well as Ellis Aizenberg, Joost Berkhout, Linda Flöthe, Jeroen Romeijn, and Patrick Statsch for their feedback in previous versions of the paper. This research received financial support from the Dutch Research Council (Nederlandse Organisatie voor Wetenschappelijk Onderzoek (NWO)), grant 452-14-012 (Vidi scheme).

Funding declaration. Dutch Research Council (Nederlandse Organisatie voor Wetenschappelijk Onderzoek (NWO)), grant 452-14-012 (Vidi scheme).

Declaration of conflicting interests. None.

\section{References}

Albareda, A. (2018), 'Connecting society and policymakers? Conceptualizing and measuring the capacity of civil society organizations to act as transmission belts', Voluntas 29(6): 1216-1232.

Albareda, A. and C. Braun (2019), 'Organizing transmission belts: the effect of organizational design on interest group access to EU policymaking', JCMS: Journal of Common Market Studies 57(3): 468-485.

Bach, T. (2014), 'The autonomy of government agencies in Germany and Norway: explaining variation in management autonomy across countries and agencies', International Review of Administrative Sciences 80(2): 341-361.

Baggetta, M. and K.D. Madsen (2018), 'The trouble with types: a partial test of the validity of membership association content as a proxy for structure', Nonprofit and Voluntary Sector Quarterly. OnlineFirst.

Baroni, L., B.J. Carroll, A.W. Chalmers, L.M.M. Marquez and A. Rasmussen (2014), 'Defining and classifying interest groups', Interest Groups \& Advocacy 3(2): 141-159.

Berkhout, J., J. Beyers, C. Braun, M. Hanegraaff and D. Lowery (2018), 'Making inference across mobilisation and influence research: comparing top-down and bottom-up mapping of interest systems', Political Studies 66(1): 43-62.

Berkhout, J., M. Hanegraaff and C. Braun (2017), 'Is the EU different? Comparing the diversity of national and EU-level systems of interest organisations', West European Politics 40(5): 1109-1131.

Bernhagen, P., J. Beyers, C. Braun, D. Fink-Hafner, F. Heylen, W.A. Maloney, . . D. Pakull (2016), INTEREURO Survey: Activities And Strategies Of European Interest Groups: A Snapshot From The INTEREURO Survey. Stuttgart.

Berry, J.M., K.E. Portney and K. Thomson (1993), The Rebirth Of Urban Democracy, Washington DC: Brookings Institution Press.

Beyers, J. (2008), 'Policy issues, organisational format and the political strategies of interest organisations', West European Politics 31(6): 1188-1211.

Beyers, J., P. Bernhagen, C. Braun, D. Fink-Hafner, F. Heylen, W.A. Maloney, . . D. Pakull (2016), INTEREURO Interest Group Survey. Data Set.

Beyers, J., R. Eising and W.A. Maloney (2008), 'Researching interest group politics in Europe and elsewhere: much we study, little we know?', West European Politics 31(6): 1103-1128.

Binderkrantz, A.S. (2009), 'Membership recruitment and internal democracy in interest groups: do group-membership relations vary between group types?', West European Politics 32(3): 657-678.

Binderkrantz, A.S. and P.M. Christiansen (2015), 'From classic to modern corporatism. Interest group representation in Danish public committees in 1975 and 2010', Journal of European Public Policy 22(7): 1022-1039.

Binderkrantz, A.S. and H.H. Pedersen (2017), 'What is access? A discussion of the definition and measurement of interest group access', European Political Science 16: 306-321.

Bouwen, P. (2002), 'Corporate lobbying in the European Union: the logic of access', Journal of European Public Policy 9(3): 365-390. https://doi.org/10.1080/13501760210138796

Bouwen, P. (2004), 'Exchanging access goods for access: a comparative study of business lobbying in the European Union institutions', European Journal of Political Research 43: 337-369.

Braun, C. (2012), 'The captive or the broker? Explaining public agency-interest group interactions', Governance 25(2): 291-314.

Bryan, T.K. (2019), 'Toward a contingency model for the relationship between capacity and effectiveness in nonprofit organizations', Nonprofit and Voluntary Sector Quarterly 48(4): 885-897.

Bunea, A. (2014), 'Explaining interest groups' articulation of policy preferences in the European commission's open consultations: an analysis of the environmental policy area', Journal of Common Market Studies 52(6): 1224-1241.

Bunea, A. (2017), 'Designing stakeholder consultations: reinforcing or alleviating bias in the European Union system of governance?' European Journal of Political Research 56(1): 46-69. 
Christensen, T., P. Lægreid and L.H. Rykkja (2016), 'Organizing for crisis management: building governance capacity and legitimacy', Public Administration Review 76(6): 887-897.

De Bruycker, I. (2016), 'Pressure and expertise: explaining the information supply of interest groups in EU legislative lobbying', Journal of Common Market Studies 54(3): 599-616.

De Bruycker, I., J. Berkhout and M. Hanegraaff (2019), 'The paradox of collective action: linking interest aggregation and interest articulation in EU legislative lobbying, Governance, 32(2): 295-312. https://doi.org/10.1111/gove.12373

Dür, A. and G. Mateo (2014), 'The Europeanization of interest groups: group type, resources and policy area', European Union Politics 15(4): 572-594.

European Commission (2001), European Governance: A White Paper, Brussels: European Commission.

European Commission (2002), Communication From The Commission: Towards A Reinforced Culture Of Consultation And Dialogue - General Principles And Minimum Standards For Consultation Of Interested Parties By The Commission, Brussels: European Commission.

European Commission (2014), Communication From The President To The Commission: The Working Methods Of The European Commission 2014-2019, Brussels: European Commission.

European Commission (2017), Stakeholder Consultation In Better Regulation Toolbox, Brussels: European Commission.

Flöthe, L. (2019a), 'Technocratic or democratic interest representation? How different types of information affect lobbying success', Interest Groups and Advocacy 8(2): 165-183.

Flöthe, L. (2019b), 'The costs of interest representation - a resource perspective on informational lobbying', European Political Science Review 11(2): 161-178.

Fraussen, B. (2014), 'The visible hand of the state: on the organizational development of interest groups', Public Administration 92(2): 406-421.

Fraussen, B., A. Albareda and C. Braun (2020), 'Conceptualizing consultation approaches: identifying combinations of consultation tools and analyzing their implications for stakeholder diversity'. Policy Sciences OnlineFirst.

Fraussen, B., J. Beyers and T. Donas (2015), 'The expanding core and varying degrees of insiderness: institutionalised interest group access to advisory councils', Political Studies 63(3): 569-588.

Greco, S., A. Ishizaka , M. Tasiou and G. Torrisi (2019, January 15), On the Methodological Framework of Composite Indices: A Review of the Issues of Weighting, Aggregation, and Robustness. Social Indicators Research. Springer Netherlands.

Greenwood, J. (2007), 'Organized civil society and democratic legitimacy in the European Union', British Journal of Political Science 37(02): 333.

Greenwood, J. (2011), Interest Representation In The European Union, Basingstoke: Palgrave Macmillan.

Grömping, M. and D.R. Halpin (2019), 'Does group engagement with members constitute a "beneficial inefficiency"?', Governance 32(3): 511-529.

Grossmann, M. (2012), The Not-so-special Interests: Interest Groups, Public Representation And American Governance, Standford, CA: Standford University Press.

Hage, J. and M. Aiken (1967), 'Relationship of centralization to other structural properties', Administrative Science Quarterly 12(1): 72-92.

Halpin, D. R. and B. Fraussen (2017), 'Conceptualising the policy engagement of interest groups: involvement, access and prominence', European Journal of Political Research 56(3): 723-732.

Halpin, D. R., B. Fraussen and A.J. Nownes (2018), 'The balancing act of establishing a policy agenda: conceptualizing and measuring drivers of issue prioritization within interest groups', Governance 31(2): 215-237.

Hanegraaff, M., J. van der Ploeg and J. Berkhout (2019), 'Standing in a crowded room: exploring the relation between interest group system density and access to policymakers', Political Research Quarterly. OnlineFirst.

Hayes, M. (1986), 'The new group universe', in A.J. Cigler and B.A. Loomis (eds.), Interest Group Politics, Washington DC: CQ Press, pp. 133-145.

Heylen, F., E. Willems and J. Beyers (2020), 'Do professionals take over? Professionalisation and membership influence in civil society organisations', VOLUNTAS: International Journal of Voluntary and Nonprofit Organizations 1-13. OnlineFirst.

Hollman, M. (2018), Interest Group Organisation in the European Union: How Internal Organisational Structures Shape Interest Group Agency, London: Routledge.

Jordan, G. and W.A. Maloney (2007), Democracy and Interest Groups: Enhancing Participation?, London: Palgrave Macmillan.

Klüver, H. (2012), 'Informational lobbying in the European Union: the effect of organisational characteristics', West European Politics 35(3): 491-510.

Klüver, H. and S. Saurugger (2013), 'Opening the black box: the professionalization of interest groups in the European Union', Interest Groups \& Advocacy 2(2): 185-205.

Kohler-Koch, B. (2010), 'Civil society and EU democracy: 'astroturf representation?', Journal of European Public Policy 17(1): 100-116. 
Kohler-Koch, B. and V. Buth (2013), 'The Balancing Act of European Civil Society - between professionalism and grassroots', in B. Kohler-Koch and C. Quittkat (eds.), The Demystification Of Participatory Governance, Oxford: Oxford University Press.

Kohler-Koch, B., P. Kotzian and C. Quittkat (2017), 'The multilevel interest representation of national business associations', West European Politics 40(5): 1046-1065.

Kröger, S. (2014), 'The involvement of the constituencies of European umbrella organizations in EU affairs', in S. Kröger (ed.), Political Representation in the European Union, London: Routledge, pp. 143-160.

Kröger, S. (2016), Europeanised or European? Representation by Civil Society Organisations in EU Policy Making, Colchester: ECPR Press.

Kröger, S. (2018), 'How limited representativeness weakens throughput legitimacy in the EU: the example of interest groups', Public Administration, 1-14.

Long, S.J. and J. Freese (2014), Regression Models For Categorical Dependent Variables Using Stata, College Station, Texas: Stata Press.

Majone, G. (1999), 'The regulatory state and its legitimacy problems', West European Politics 22(1): 1-24. https://doi.org/10. $1080 / 01402389908425284$

Maloney, W.A. (2015), 'organizational populations: professionalization, maintenance and democracy delivery', in D. Lowery, D.R. Halpin and V. Gray (eds.), The Organizational Ecology Of Interest Communities: Assessment And Agenda, London: Palgrave Macmillan, pp. 99-116.

Maloney, W.A., G. Jordan and A.M. McLaughlin (1994), 'Interest groups and public policy: the insider/outsider model revisited', Journal of Public Policy 14(1): 17-38.

Minkoff, D., S. Aisenbrey and J. Agnone (2008), 'Organizational diversity in the U.S. advocacy sector', Social Problems 55(4): 525-548.

Pérez-Solórzano Borragán, N. (2014), 'The European Commission and political representation: a new inter-institutional perspective', in S. Kröger (ed.), Political Representation In The European Union, London: Routledge, pp. 125-142.

Persson, M., P. Esaiasson and M. Gilljam (2013), 'The effects of direct voting and deliberation on legitimacy beliefs: an experimental study of small group decision-making', European Political Science Review 5(3): 381-399.

Persson, T. and K. Edholm (2018), 'Assessing the effects of European Union funding of civil society organizations: money for nothing?' Journal of Common Market Studies 56(3): 559-575.

Pugh, D.S., D.J. Hickson, C.R. Hinings, K.M. Macdonald, C. Turner and T. Lupton (1963), 'A conceptual scheme for organizational analysis', Administrative Science Quarterly 8(3): 289-315.

Rasmussen, A., B.J. Carroll and D. Lowery (2014), 'Representatives of the public? Public opinion and interest group activity', European Journal of Political Research 53(2): 250-268.

Rasmussen, A. and V. Gross (2015), 'Biased access? Exploring selection to advisory committees', European Political Science Review 7(3): 343-372.

Rasmussen, A. and D. Toshkov (2013), The effect of stakeholder involvement on legislative duration: consultation of external actors and legislative duration in the European Union. European Union Politics 14: 366-387.

Saurugger, S. (2008), 'Interest groups and democracy in the European Union', West European Politics 31(6): 1274-1291.

Schlozman, K.L., P.E. Jones, H.Y. You , T. Burch, S. Verba and H.E. Brady (2015), 'Organizations and the democratic representation of interests: what does it mean when those organizations have no members?', Perspectives on Politics 13(04): 1017-1029.

Schmitter, P.C. and W. Streeck (1999), 'The organization of business interests: Studying the associative action of business in advanced industrial societies,', MPIfG Discussion Paper 99/1, Max Planck Institute for the Study of Societies.

Skocpol, T. (2003), Diminished Democracy. From Membership To Management In American Civic Life, Norman: University of Oklahoma Press.

van der Pijl, K. and H. Sminia (2004), 'Strategic management of public interest organizations', Voluntas 15(2): $137-155$.

Walker, E.T., J.D. Mccarthy and F. Baumgartner (2011), 'Replacing members with managers? Mutualism among membership and nonmembership advocacy organizations in the United States', American Journal of Sociology 116(4): 1284-1337.

Weiler, F., S. Eichenberger, A. Mach and F. Varone (2019), 'More equal than others: assessing economic and citizen groups' access across policymaking venues', Governance 32(2): 277-293. https://doi.org/10.1111/gove.12372

Willems, E. (2020), 'Politicised policy access. The effect of politicisation on interest group access to advisory councils', Public Administration, OnlineFirst.

Cite this article: Albareda A (2020). Prioritizing professionals? How the democratic and professionalized nature of interest groups shapes their degree of access to EU officials. European Political Science Review 12, 485-501. https://doi.org/10.1017/ S1755773920000247 